\title{
Corruption, the resource curse and genuine saving
}

\author{
SIMON DIETZ and ERIC NEUMAYER* \\ Department of Geography and Environment and Centre for Environmental \\ Policy and Governance, London School of Economics and Political Science, \\ Houghton Street, London WC2A 2AE, UK
}

\section{INDRA DE SOYSA}

Department of Sociology and Political Science, Norwegian University of Science and Technology, Trondheim, Norway

\begin{abstract}
Genuine saving is a measure of net investment in produced, natural and human capital. It is a necessary condition for weak sustainable development that genuine saving not be persistently negative. However, according to data provided by the World Bank, resource-rich countries are systematically failing to meet this condition. Alongside the well-known resource curse on economic growth, resource abundance might have a negative effect on genuine saving. In fact, the two are closely related, as future consumption growth is limited by insufficient genuine saving now. In this paper, we apply the most convincing conclusion from the literature on economic growth - that it is institutional failure that depresses growth - to data on genuine saving. We regress gross and genuine saving on three indicators of institutional quality in interaction with an indicator of resource abundance. The indicators of institutional quality are corruption, bureaucratic quality and the rule of law. We find that reducing corruption has a positive impact on genuine saving in interaction with resource abundance. That is, the negative effect of resource abundance on genuine saving is reduced as corruption is reduced.
\end{abstract}

\section{Introduction}

Genuine saving (hereafter GS) is an established measure of weak sustainable development. Weak sustainable development is built on the assumption that different forms of capital are substitutable for each other (Neumayer, 2003). ${ }^{1}$ Development is unsustainable if an economy's total stock of capital is eroded, which, for instance, will occur if the GS rate is (persistently) allowed to drop below zero. Since GS was developed, the World Bank (2004) has made retrospective calculations for more than 150 countries between 1970 and the present day. Although it finds that global

\section{* Corresponding author. Phone: 0207-9557598. Email: e.neumayer@lse.ac.uk}

Thanks to Kirk Hamilton, Anastasios Xepapadeas and two anonymous referees for many helpful and constructive comments. The usual disclaimer applies. Eric Neumayer acknowledges financial assistance from the Leverhulme Trust.

${ }^{1}$ As opposed to strong sustainable development, which assumes natural capital is either partly or wholly non-substitutable. 
GS has been consistently positive, over the whole of this period GS rates have been alarmingly low and consistently negative in certain countries of the world. Significantly, these countries are also often resource-rich.

This observation is strongly reminiscent of the so-called 'resource curse' hypothesis in the economic growth literature: the phenomenon that resource-rich economies generally grow more slowly than resource-poor economies. Indeed, the two phenomena are linked: first, current genuine savings should in theory be equal to growth in the present value of future well-being along the optimal growth path of the economy, even though empirical evidence does not fully fit the theory (Ferreira and Vincent, 2005; World Bank, 2005). In other words, countries with poor GS performance should also perform poorly in terms of future economic growth. Second, resource-abundant countries with slow growth in the past and negative GS are unlikely to be able to sustain even their comparatively small increases in income into the future.

The resource curse represents a puzzle since the free gift of nature in the form of natural resource deposits should be a blessing, not a curse to the economy. Unsurprisingly, the resource curse on economic growth has generated a substantial literature over the past half-century or more. Many explanations have been put forward and one can broadly distinguish between more directly economic explanations and political-economic explanations that highlight the role of policy and/or institutional failure. Ultimately, it is difficult to resist the conclusion that it is political-economic failures that have been the root cause of slow growth. We draw succour from this finding and examine whether low GS rates in resource-rich countries can similarly be explained by particular political and institutional failings. More specifically, we test whether improving institutional quality in selected, distinct ways leads resource-rich countries to invest their resource rents more sustainably in other forms of capital.

Atkinson and Hamilton (2003) have made a useful first attempt to address these issues. They provide tentative evidence of an interaction between a composite index of general institutional quality, also used by Sachs and Warner (1995), and resource abundance in determining gross saving/investment: resource-rich countries with good quality institutions have enjoyed greater rates of gross investment and saving. We build on Atkinson and Hamilton's (2003) research in several ways. First and foremost, we test whether this interaction holds for genuine saving as well as gross saving/investment. Secondly, we test whether specific aspects of institutional quality are more significant than others in driving up GS. We examine three indicators of institutional quality to assess which aspect of institutional quality it is that matters most: corruption, bureaucratic quality and the rule of law. Thirdly, whereas Atkinson and Hamilton (2003) use a cross-section of period-average data, we use a panel of data spanning up to 115 countries and 18 years. This allows us to estimate the interaction with more sophisticated econometric techniques that allow for country-specific effects, which are likely to be correlated with both resource abundance and institutional quality, and that allow for dynamic effects. Our most important result is that resource-rich countries suffer from low GS rates, but that they 
can improve their performance by fighting corruption, difficult as this may be in actuality.

Section 2 explains GS in more detail, and outlines the empirical finding that resource abundance is negatively related to GS. Section 3 discusses the resource curse in terms of the growth literature. Section 4 explains our empirical strategy, section 5 outlines our results and section 6 provides a discussion.

\section{Genuine saving and resource abundance: the unsustainable consumption of resource rents}

The origins of GS can be traced back to the work of Solow (1974) and Hartwick (1977), who were concerned with maximising intertemporal social welfare in an economy exploiting a non-renewable resource. Given a range of simplifying assumptions, ${ }^{2}$ this is realised through an optimal mix of consumption and investment. Total investment across the economy is the sum of net changes in the capital stock valued at its shadow price. If GS is persistently below zero, then the economy is certainly not weakly sustainable (Hamilton and Clemens, 1999). The World Bank calculations of GS, which it now calls "adjusted net saving", includes three forms of capital: produced, natural and human. GS is computed as follows (appendix I provides more details):

GS = investment in produced capital - net foreign borrowing

+ net official transfers - depreciation of produced capital

- net depreciation of natural capital + current education expenditures

World Bank GS estimates for the period 1970-2001 have shown significant differences from country to country. One important trend to emerge is that resource-rich countries are the poorest genuine savers (see also Atkinson and Hamilton, 2003). Figure 1 plots period-average GS rates (that is, GS divided by gross national income) against resource abundance for 145 countries. Resource abundance is measured as the average share of fuel and mineral product exports in total exports.

With the exception of Algeria and Guinea, for whom GS was just above zero for the period 1970-2001, every country with an average share of fuel and mineral exports in total exports of over $60 \%$ had negative GS. In contrast, most resource-poor countries, especially the cluster of countries with an average share of fuel and mineral exports in total exports of under $20 \%$, had positive GS. In Sub-Saharan Africa, it must also be said that net produced capital investment is often negative too. In other words, the total 'man-made' wealth of these countries is also decreasing, and the World Bank's estimates of net natural capital depreciation simply worsen the situation. This is the case in Guinea-Bissau, for example. Nevertheless, one important conclusion we can draw from the World Bank's data is that the countries with the greatest natural resource extraction are also the poorest performers in terms of GS. Put another way, they are failing to invest a

2 See Dietz and Neumayer (2004). 


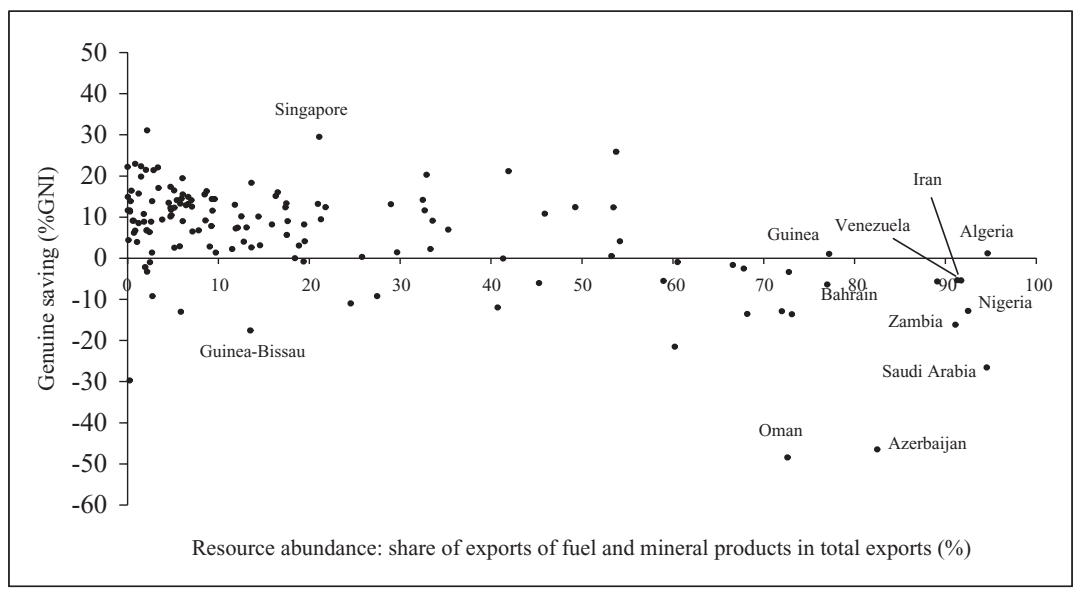

Figure 1. Resource abundance and genuine saving between 1970 and 2001 (data from World Bank 2004)

sufficient proportion of their resource rents into other forms of capital. This is striking, because it bears a considerable similarity to arguments made with respect to the effect of natural resource intensity on economic growth.

It is important to note that the method the Bank applies to estimate net depreciation of natural capital (price minus average cost times amount of resource extraction) is likely to over-estimate the true extent of depreciation in countries with a large stock of remaining resources (Neumayer, 2000, 2003). This is because contrary to, for example, the usercost approach of the El Serafy (1981) method, it does not acknowledge that resource extraction carries an element of both capital depreciation and true income. However, lack of reserve data prevents us from adjusting the GS figures and whilst the data published by the Bank are likely to over-estimate natural capital depreciation and therefore under-estimate GS rates in resource-rich countries, it is our view that the main result on the interaction between institutional quality and resource abundance is unlikely to change in qualitative terms if a different method for calculating natural capital depreciation is used. One would have to be concerned if the extent of under-estimation of GS were systematically correlated with institutional quality, but we see no reason why this should be the case.

\section{The 'resource curse' hypothesis and policy failure}

"One of the surprising features of economic life is that resource-poor economies often vastly outperform resource-rich economies in economic growth" (Sachs and Warner, 1995, p. 2). Instances of this can be found throughout modern history, but it is especially true of the post-1970 period. Between 1970 and 1993, per capita GDP in resource-rich countries grew around three times slower than it did in resource-poor countries 
(Auty, 2001). Perhaps this is because resource-abundance masks underlying trends in other determinants of economic growth such as trade policy and government efficiency. However, Sachs and Warner (1995) demonstrated that, even after controlling for these factors, resource-abundance is negatively related to growth. The phenomenon has become known as the 'resource curse'.

The fact that fuel and mineral-rich economies perform especially badly in relation to resource-poor economies (Auty, 2001) is a paradox. On the face of it, countries with abundant fuel and mineral resources ought to be able to sustain rapid growth both in the short and medium-term, as long as they invest the proceeds of their resource windfalls in other productive forms of capital. A number of explanations for the resource curse have been put forward. We are especially interested in these, because they may help to cast some light on the causes of insufficient GS in resource-rich countries. A popular explanation surrounds the poor economic performance of the natural resources sector - characterised by falling primary resource prices (Prebisch, 1962), vulnerability to short-term price fluctuations (Sala-iMartin and Subramanian, 2003) and relatively sluggish demand-compared to the manufacturing sector. But we must ask why resource-rich countries have not succeeded in diversifying? They ought to be able to invest their resource rents in other forms of capital, and lay the foundations for faster and sustainable growth.

One reason why they might not is the so-called 'Dutch disease', whereby the discovery of new resource stocks leads the real exchange rate (or real wages) to over-appreciate, which perversely causes the tradeable non-resource sector to contract. Many economists believe that the manufacturing sector (and indeed the service sector) produces more positive externalities than the natural resources sector (e.g. learning-bydoing). Thus the contraction of the manufacturing sector in relative terms could depress economic activity (Hirschman, 1958; Matsuyama, 1992). From an investment perspective, there may not be an incentive to invest in manufactures under these circumstances. Resource-rich countries may also lack the incentive to make productive investments in human capital through educational expenditure (Birdsall et al., 2001; Gylfason, 2001; Papyrakis and Gerlagh, 2004a, 2004b). This may be connected to Dutch disease, insofar as currency appreciation may reduce the relative rate of return to educational investments.

However, it seems plausible that it is a failure of public policy causing this underinvestment. Judicious management of natural resource endowments can prevent the generation of too much income too quickly. In Norway, for example, the government takes around $80 \%$ of resource rents in taxes and fees and invests that amount in foreign assets (Gylfason, 2001). Either governments with abundant natural resources are blind to the need to invest in produced and human capital because they see themselves in a 'comfort zone', or they may even deliberately neglect to invest. Either way, this leads us more generally to a political-economic explanation of the resource curse.

The potential to 'cash in' on natural resources may have an unsettling and inhibiting effect on a country's polity, leading to injudicious decisions on 
the economy. The availability of resource rents may give rise to corruption. ${ }^{3}$ There are multiple reasons why corruption may in turn slow economic growth (Leite and Weidmann, 1999) by reducing investment and the productivity of investment (Boycko et al., 1995; Mauro, 1995; Murphy et al., 1993; Romer, 1994). Alternatively, Isham et al. (2003) have identified wider political-economic explanations for the resource curse. Firstly, the whole state may be subject to a 'rentier effect'. States with abundant mineral and oil reserves extract their revenues from resources that are concentrated geographically and in terms of ownership. This reduces their incentive to develop the governance mechanisms that enable general taxation. On the opposite side, since the state sector tends to dominate, citizens have less incentive to form a healthy 'civil society', an independent middle class fails to develop, and technocratic and entrepreneurial talent remains captive of state largesse in terms of employment and advancement opportunities (Chaudhry, 1997). In addition, the government can rely on its resource revenues to repress dissent, either through buying off opposition (often with high-profile 'white elephant' infrastructure projects) or through violence. As a result of this, democracy often fails to develop (Karl, 1997; Ross, 2001). More importantly in this context, stifling technocratic and entrepreneurial talent, as well as making unproductive 'white-elephant' investments, will harm the economy.

Secondly, political elites find it relatively easy to control resources and maintain their wealth in a point resource-led economy, but face the prospect of losing their grip through industrialisation and urbanisation (Acemoglu et al., 2001; Moore, 1967). It follows that political elites in resource-rich countries resist modernisation pressures for as long as possible, especially investment in the manufacturing sector. Again, in this case civil society fails to develop. The main reason for this is that the concentration of capital ownership among political elites, together with production methods that favour the use of expert (foreign) labour and that are capital-intensive (Auty and Kiiski, 2001), reproduces social inequalities between those inside the elite and those outside it.

Hence we are compelled to test whether the negative effect of resource abundance on GS is explained by policy failure. In particular, we specify a model to explain GS based on the interaction between natural resource endowments and institutional quality. Atkinson and Hamilton (2003) found a significant positive interaction between resource abundance and general institutional quality on gross investment and saving. According to their results, resource-rich countries with good quality institutions have enjoyed greater rates of gross investment and saving. We extend their logic to GS and also test whether some elements of institutional quality are more important than others in explaining variations in GS. We test corruption, based on the expectation that it will divert the proceeds of natural resource liquidation away from investment in produced and human capital towards consumption. We also test measures of bureaucratic quality and the rule of law. Following Isham et al. (2003), we decline to apportion these three

\footnotetext{
${ }^{3}$ Known as rapacious rent-seeking behaviour (Lane and Tornell, 1996; Torvik, 2002).
} 
indicators to particular theories. Instead, we test whether it is indeed true that these wider political economy effects depress GS, or whether it is corruption in particular that matters.

\section{Empirical strategy}

We model variations in rates of gross savings and GS in a panel of data spanning up to 115 countries and 18 years. We specify a reducedform model, with a particular focus on the interaction between resource abundance and indicators of institutional quality. It is ultimately GS that we are interested in. However, we start with gross savings, since it is gross savings that "anchors" GS and we want to investigate whether the interaction between resource abundance and indicators of institutional quality impact the gross and GS rates differentially.

\section{Determinants of (gross) saving}

Within the last fifteen years, a number of studies have analysed the empirical determinants of gross private or gross national saving ${ }^{4}$ using panel data and reduced-form models (Edwards, 1996; Dayal-Gulati and Thimann, 1997; Loayza et al., 2000; Corbo and Schmidt-Hebbel, 1991; Masson et al., 1995; Haque et al., 1999; Samwick, 2000). Across all studies, four variables appear to have a robust and significant effect on gross saving: (i) per capita income, (ii) economic growth, (iii) age dependency and (iv) urbanisation. Income per capita and income growth have a positive effect on gross (private) saving. Age dependency has a negative effect on gross saving, and in the empirical studies, urbanisation tends to have a negative effect on gross saving. A number of other variables are tested in the above studies. We choose not to include them for three reasons. Firstly, some are generally insignificant in the empirical literature. These include macroeconomic indicators such as interest rates and terms-of-trade. Secondly, data availability for some variables is very limited. These include detailed indicators of financial liberalisation, social security systems and income inequality. Thirdly, some are components of GS, and therefore including them as independent variables effectively constructs a partial identity with the dependent variable. These include fiscal policy variables such as government consumption and fiscal surplus (see appendix I).

\section{Hypothesis and data}

We test the following two hypotheses:

Hypothesis 1: Resource-rich countries have higher rates of gross saving and the effect is stronger the better is institutional quality.

Hypothesis 2 (main hypothesis): Resource-rich countries have lower rates of genuine savings, but this effect is likely due to policy failure and raising institutional quality in these countries will lead to greater investment of resource rents in other forms of capital, and thus to higher rates of genuine saving.

\footnotetext{
${ }^{4}$ Where gross national saving $=$ gross private saving + gross public saving.
} 
We test these hypotheses with the following models

$$
\begin{aligned}
\text { GrossSR }_{i, t}= & \alpha+\beta_{1} \ln Y_{i, t}+\beta_{2} \text { Growth }_{i, t-1}+\beta_{3} \text { Age }_{i, t}+\beta_{4} \text { Urban }_{i, t} \\
& +\beta_{5} \text { Inst }_{i, t}+\beta_{6} \text { Rs }_{i, t}+\beta_{7} \text { Inst }_{i, t} * \text { Rs }_{i, t}+T_{t}+\varepsilon_{i, t} \\
\text { GSR }_{i, t}=\alpha & +\beta_{1} \ln Y_{i, t}+\beta_{2} \text { Growth }_{i, t-1}+\beta_{3} \text { Age }_{i, t}+\beta_{4} \text { Urban }_{i, t} \\
& +\beta_{5} \text { Inst }_{i, t}+\beta_{6} \text { Rs }_{i, t}+\beta_{7} \text { Inst }_{i, t} * \text { Rs }_{i, t}+T_{t}+\varepsilon_{i, t}
\end{aligned}
$$

for country $i$ at time $t$, where $\varepsilon$ is an error term. The year dummies $T$ allow for global changes in the gross savings and GS rates over time not otherwise accounted for in the explanatory variables. Gross $S R$ is the gross savings rate, GSR is the GS rate. Data are taken from the World Bank; ${ }^{5} \ln Y$ is gross national income per capita. We take the natural log to account for positive skewness. Growth is GDP growth, which is lagged one year to mitigate potential endogeneity bias; Age is the age-dependency ratio: the ratio of dependants - people younger than 15 and older than 64 - to the workingage population (those aged 15-64); Urban is a measure of urbanisation: the percentage of the total population living in urban areas. Data for all these variables are taken from the World Bank's World Development Indicators Online database (World Bank, 2004).

Inst is institutional quality. We separately test three indicators of institutional quality. Indices of (i) lack of corruption, (ii) bureaucratic quality and (iii) the rule of law are taken from the International Country Risk Guide (ICRG). These are scaled from 0 , which indicates poor quality institutions (i.e. the highest corruption, the lowest bureaucratic quality and the absence of rule of law) to 6, which indicates high quality institutions (i.e. the lowest corruption, the highest bureaucratic quality and full rule of law). ${ }^{6}$ The indices are compiled in an attempt to assess the investment risk faced by multinational companies and are based on expert judgements. Insofar as they ought to be positively related to investment, they are promising for our purposes. Unfortunately, the ICRG variables are only available for the period 1984 to 2001.

Rs: Atkinson and Hamilton (2003) use the value of resource rents. We cannot take this measure since resource rents form part of GS and their inclusion would lead to a partial identity of the left-hand and right-hand sides of the estimating equation. Instead, we take the combined share of fossil fuel and mineral products in total exports as our measure of resource abundance (World Bank, 2004). This is similar to the measure used by Sachs and Warner (1995) in their seminal paper and the most widely used measure in the literature on the resource curse. The difference is that we do not include agricultural products, the inclusion of which has been widely criticised, as Sachs and Warner (2001) themselves admit. Ideally, one would want to measure resource abundance with measures of

\footnotetext{
${ }^{5}$ http://lnweb18.worldbank.org/ESSD/envext.nsf/44ByDocName/ GreenAccountingAdjustedNetSavings

${ }^{6}$ Until 1996, bureaucratic quality was scored $0-4$. We rescale this data to lie between 0 and 6 . However, none of the observations in our sample actually have a score of zero.
} 
resource stocks, as others have noted before (Stijns, 2002; Bulte et al., 2005). However, no comprehensive data on resource stocks exist. Our expectation is that resource abundance as measured by the combined share of fossil fuel and mineral products in total exports will be negatively associated with the GS rate. This effect could be partly due to the way the World Bank measures GS. As mentioned already, in subtracting the full resource rents from gross savings, the World Bank employs a method for calculating the value of natural resource stock depreciation that is likely to represent an over-estimate and is thereby under-estimating the GS rate in resourceabundant countries (see Neumayer, 2000, 2003). However, other methods of accounting for natural resource stock depreciation are contestable as well and/or are extremely data-intensive. For example, the El Serafy (1981) method requires information on resource stocks, which are difficult to get, as mentioned above. Importantly, our main hypothesis is that the negative effect of resource abundance is moderated by the degree of institutional quality. For this conditional effect, the fact that the GS rate is likely to be under-estimated for resource-abundant countries should not matter, unless the under-estimation were systematically correlated with institutional quality. We see no reason why this should be the case.

$\ln Y$, Growth, Age, and Urban are the control variables. Inst, Rs and its interaction term are the main variables of interest. As noted above, we expect $R s$ to have a negative effect on GS. However, if raising the standard of institutions in resource-rich countries reduces the unsustainable consumption of resource rents, then we would expect the interaction term $I n s t^{*} R s$ to be positive. Rs is the predictor variable and Inst is the moderator variable, such that the negative relationship between resource abundance and GS becomes more positive - i.e. improves - the better are the political institutions. Where the interaction term is significant, one cannot interpret the coefficients on the individual components $R s$ and Inst in the conventional way. Instead, the coefficient on $R s$ in a model with a significant interaction term Inst* Rs is the slope of Rs on GS when Inst is equal to zero.

\section{Estimation strategy}

We first estimate the model with fixed effects, a design that allows for unobserved time-invariant variation in country-specific factors, with robust standard errors. Secondly, we estimate the model using the ArellanoBond linear, dynamic panel-data estimator (Arellano and Bond, 1991). This accounts for the inertia that is almost certainly present in the determination of saving rates (Loayza et al., 2000). The Arellano-Bond estimator is a generalised-method-of-moments (GMM) estimator. It is constructed by first-differencing the dependent and independent variables. Although the Arellano-Bond estimator has advantages over a static fixed effects estimator, it also suffers from problems. First-differencing wipes out the country fixed effects, but the lagged dependent variable is by definition correlated with the error term such that further lags of the dependent variable and first differences of the exogenous explanatory variables are used as instruments. This leads to rather inefficient estimation with high standard errors if Arellano and Bond's (1991) one-step estimator with robust standard errors is used. The two-step estimator is much more efficient, but can 
under-estimate the size of standard errors in small samples. As a result of this, we report estimation results from both the one-step and the twostep estimator. Moreover, whilst first-order serial correlation is expected, second-order serial correlation indicates that the original error term is serially correlated, which renders the estimations inconsistent. In all our estimations reported below we can reject the hypothesis of second-order serial correlation at conventional levels of significance.

One potential problem is that institutional quality might be endogenous. In other words, while institutional quality affects the GS rate, the GS rate might also affect institutional quality. In econometric terms, this would mean that institutional quality is correlated with unobserved variables that enter the error term. As long as these unobserved variables are timeinvariant, this is not a problem since we use fixed-effects or first-differenced models. It is possible, however, that unobserved variables vary over time. Ideally, one would tackle this problem with the help of the instrumental variables regression technique. The problem is that potential instruments such as geography and historical information on settler mortality suggested by the literature on the effect of institutions on growth are all time-invariant and are used in cross-sectional regression analysis (Acemoglu et al., 2001; Rodrik et al., 2004; Glaeser et al., 2004). It is not possible to estimate a fixedeffects instrumental variable regression model with instruments that do not vary over time and we believe that controlling for fixed effects is of paramount importance to our estimations.

\section{Results}

Table 1 reports summary statistics and a bivariate correlation matrix. Although the lack of corruption, bureaucratic quality and rule of law indices are all compiled by ICRG, the correlations between them are not especially high. In particular, the strength of correlation between lack of corruption and bureaucratic quality and between lack of corruption and the rule of law is only moderate ( 0.54 and 0.52 respectively). Therefore there may indeed be a possibility of detecting different effects between the various measures of institutional quality and GS.

Table 2 presents the static fixed effects estimations for the gross savings rate, with columns 1-3 reporting results for each of the three indicators of institutional quality. Looking initially at the control variables, GDP growth is a significant and positive determinant of the GrossSR in all models, whereas the age-dependency ratio and the urbanization rate are negative determinants. Resource-abundant countries do not have higher rates of gross savings and there is no evidence for an interaction effect with institutional quality either in static estimation. ${ }^{7}$

Perhaps this is because the static fixed-effects estimation does not take into account the dynamics of savings behaviour. Table 3 reports the results of our estimations with the Arellano-Bond dynamic model. In this case, the GrossSR is also regressed on itself and is positive and highly significant in all

${ }^{7}$ We found no consistent evidence for a non-linear effect of resource abundance and its interaction effects with institutional quality and therefore enter the variables in linear form only. 
Table 1. Summary statistics and correlation matrix

\begin{tabular}{|c|c|c|c|c|c|c|c|c|c|c|}
\hline & $N$ & & Mean & & Std. Dev. & & Min. & & $\operatorname{Max}$. & \\
\hline Gross Savings/GNI & 1338 & & 20.29 & & 8.57 & & -33.04 & & 54.23 & \\
\hline Genuine Saving/GNI & 1158 & & 8.24 & & 11.71 & & -54.89 & & 44.32 & \\
\hline GNI per capita (ln) & 1338 & & 7.98 & & 1.46 & & 4.70 & & 10.69 & \\
\hline GDP growth (lagged one year) & 1338 & & 3.40 & & 4.09 & & -13.38 & & 33.99 & \\
\hline Age-dependency & 1338 & & 0.65 & & 0.17 & & 0.37 & & 1.17 & \\
\hline Urbanisation & 1338 & & 60.72 & & 21.98 & & 10.01 & & 100 & \\
\hline Resource exports & 1338 & & 21.99 & & 26.85 & & 0.02 & & 99.70 & \\
\hline Lack of corruption & 1206 & & 3.54 & & 1.37 & & 0 & & 6 & \\
\hline Bureaucratic quality & 1338 & & 3.87 & & 1.45 & & 1 & & 6 & \\
\hline \multirow{2}{*}{ Rule of law } & 1338 & & 3.95 & & 1.53 & & 0 & & 6 & \\
\hline & $\mathrm{I}$ & II & III & IV & V & VI & VII & VIII & IX & $X$ \\
\hline I: Gross Saving/GNI & 1.00 & & & & & & & & & \\
\hline II: Genuine Saving/GNI & 0.59 & 1.00 & & & & & & & & \\
\hline III: GNI per capita (ln) & 0.33 & 0.19 & 1.00 & & & & & & & \\
\hline IV: GDP growth & 0.24 & 0.15 & -0.07 & 1.00 & & & & & & \\
\hline V: Age-dependency & -0.47 & -0.34 & -0.73 & -0.03 & 1.00 & & & & & \\
\hline VI: Urbanisation & 0.20 & 0.01 & 0.77 & -0.09 & -0.57 & 1.00 & & & & \\
\hline VII: Resource exports & -0.05 & -0.62 & -0.13 & -0.03 & 0.26 & 0.10 & 1.00 & & & \\
\hline VIII: Lack of corruption & 0.02 & 0.04 & 0.52 & -0.07 & -0.30 & 0.27 & -0.18 & 1.00 & & \\
\hline IX: Bureaucratic quality & 0.32 & 0.31 & 0.77 & 0.00 & -0.64 & 0.48 & -0.30 & 0.54 & 1.00 & \\
\hline X: Rule of law & 0.28 & 0.18 & 0.70 & 0.03 & -0.62 & 0.46 & -0.17 & 0.52 & 0.70 & 1.00 \\
\hline
\end{tabular}


Table 2. Static fixed effects estimates (gross savings rate)

\begin{tabular}{|c|c|c|c|}
\hline & $\begin{array}{l}\text { 'Lack of } \\
\text { corruption' }\end{array}$ & $\begin{array}{c}\text { 'Bureaucratic } \\
\text { quality' }\end{array}$ & $\begin{array}{l}\text { 'Rule of } \\
\text { law' }\end{array}$ \\
\hline & 1 & 2 & 3 \\
\hline \multirow[t]{2}{*}{ GNI per capita (ln) } & 1.361 & 0.472 & 0.629 \\
\hline & $(0.903)$ & $(0.958)$ & $(0.927)$ \\
\hline \multirow[t]{2}{*}{ GDP growth th-1 $_{t}$} & $0.141^{* *}$ & $0.163^{* *}$ & $0.166^{* *}$ \\
\hline & $(0.046)$ & $(0.044)$ & $(0.044)$ \\
\hline \multirow[t]{2}{*}{ Age dependency } & $-23.543^{* *}$ & $-20.914^{* *}$ & $-21.106^{* *}$ \\
\hline & $(4.920)$ & (4.593) & (4.741) \\
\hline \multirow[t]{2}{*}{ Urbanisation } & $-0.219^{* *}$ & $-0.173^{*}$ & $-0.159^{*}$ \\
\hline & $(0.076)$ & $(0.076)$ & $(0.075)$ \\
\hline \multirow[t]{2}{*}{ Resource exports } & -0.015 & 0.014 & 0.007 \\
\hline & $(0.032)$ & $(0.034)$ & $(0.035)$ \\
\hline \multirow[t]{2}{*}{ Institutional quality } & 0.332 & $0.693^{*}$ & 0.356 \\
\hline & $(0.234)$ & $(0.312)$ & $(0.230)$ \\
\hline Resource exports* & -0.014 & -0.015 & -0.011 \\
\hline Inst. quality & $(0.008)$ & $(0.010)$ & $(0.008)$ \\
\hline $\mathrm{R}^{2}$ within & 0.09 & 0.09 & 0.08 \\
\hline$N$ observations & 1222 & 1338 & 1338 \\
\hline$N$ countries & 107 & 115 & 115 \\
\hline
\end{tabular}

Notes: Dependent variable is GrossSR (Gross Savings/GNI). Year-specific time dummies included. Robust standard errors in parentheses. * Significant at $5 \%$, ** at $1 \%$.

cases. Economic growth and the age-dependency ratio remain statistically significant determinants, but the urbanisation rate is only significant in model $1 \mathrm{~b}$. There is now evidence, if only in the more efficient two-step estimation, that resource abundance in interaction with lack of corruption (model 1b) and the rule of law (model $3 b$ ) is associated with a higher gross savings rate.

The results reported for gross savings are interesting, but ultimately it is GS, not gross savings, that matters for weak sustainable development. The question is whether our main hypothesis that posits an interaction effect between resource abundance and institutional quality is corroborated by empirical evidence or not.

Table 4 presents the static fixed effects estimations for the GSR, with columns 1-3 again reporting results for each of the three indicators of institutional quality. Looking initially at the control variables, GNI per capita and GDP growth are significant and positive determinants of the GSR in all models. The age-dependency ratio and the urbanization rate are not significant in any model. This is somewhat different from the GrossSR, for which GNI per capita was insignificant, whereas the age-dependency ratio and the urbanization rate were negative determinants. This would suggest that gross and genuine savings are determined differently. In terms of our main hypothesis, the explanatory variable of main interest 
Table 3. Dynamic Arellano-Bond estimates (gross savings rate)

\begin{tabular}{|c|c|c|c|c|c|c|}
\hline & \multicolumn{2}{|c|}{ 'Lack of corruption' } & \multicolumn{2}{|c|}{ 'Bureaucratic quality' } & \multicolumn{2}{|c|}{ 'Rule of law' } \\
\hline & $\begin{array}{c}\text { One-step } \\
1 a\end{array}$ & $\begin{array}{c}\text { Two-step } \\
1 b\end{array}$ & $\begin{array}{c}\text { One-step } \\
2 a\end{array}$ & $\begin{array}{c}\text { Two-step } \\
2 b\end{array}$ & $\begin{array}{c}\text { One-step } \\
3 a\end{array}$ & $\begin{array}{c}\text { Two-step } \\
3 b\end{array}$ \\
\hline \multirow{2}{*}{$(\mathrm{GS} / \mathrm{GNI})_{t-1}$} & $0.431^{* *}$ & $0.429^{* *}$ & $0.410^{* *}$ & $0.411^{* *}$ & $0.420^{* *}$ & $0.454^{* *}$ \\
\hline & $(0.077)$ & $(0.021)$ & $(0.079)$ & $(0.015)$ & $(0.081)$ & $(0.019)$ \\
\hline \multirow[t]{2}{*}{ GNI per capita (ln) } & 0.312 & -0.476 & -0.139 & -0.243 & -0.125 & -0.832 \\
\hline & $(1.277)$ & $(1.061)$ & $(1.498)$ & $(0.691)$ & $(1.357)$ & $(0.749)$ \\
\hline \multirow[t]{2}{*}{ GDP growth $_{t-1}$} & $0.128^{* *}$ & $0.134^{* *}$ & $0.123^{*}$ & $0.115^{* *}$ & $0.123^{*}$ & $0.137^{* *}$ \\
\hline & $(0.048)$ & $(0.016)$ & $(0.052)$ & $(0.013)$ & $(0.050)$ & $(0.012)$ \\
\hline \multirow[t]{2}{*}{ Age dependency } & $-26.487^{*}$ & $-29.047^{* *}$ & $-22.875^{*}$ & -12.578 & $-21.478^{*}$ & $-20.099^{* *}$ \\
\hline & $(10.595)$ & $(6.928)$ & $(10.510)$ & (6.983) & $(10.010)$ & $(7.481)$ \\
\hline \multirow[t]{2}{*}{ Urbanisation } & -0.221 & $-0.466^{* *}$ & -0.081 & 0.078 & -0.154 & 0.044 \\
\hline & $(0.193)$ & $(0.141)$ & $(0.214)$ & $(0.173)$ & $(0.198)$ & $(0.150)$ \\
\hline \multirow[t]{2}{*}{ Institutional quality } & 0.116 & 0.198 & -0.158 & -0.053 & 0.169 & -0.403 \\
\hline & $(0.243)$ & $(0.216)$ & $(0.512)$ & $(0.362)$ & $(0.479)$ & $(0.350)$ \\
\hline \multirow[t]{2}{*}{ Resource exports } & -0.041 & $-0.039^{*}$ & 0.036 & 0.039 & -0.016 & $-0.037^{*}$ \\
\hline & $(0.063)$ & $(0.019)$ & $(0.056)$ & $(0.022)$ & $(0.073)$ & $(0.016)$ \\
\hline Resource exports* & 0.017 & $0.016^{* *}$ & -0.006 & -0.007 & 0.014 & $0.022^{* *}$ \\
\hline Inst. quality & $(0.013)$ & $(0.004)$ & $(0.017)$ & $(0.007)$ & $(0.019)$ & $(0.004)$ \\
\hline Wald $\mathrm{Chi}^{2}$ & 219.5 & 4746.3 & 217.5 & 28683.5 & 209.1 & 20198.6 \\
\hline 2nd order serial & -0.01 & 0.04 & 0.09 & 0.14 & 0.20 & 0.23 \\
\hline autocorrelation & (0.9947) & $(0.9719)$ & $(0.9250)$ & $(0.8870)$ & $(0.8410)$ & $(0.8206)$ \\
\hline$N$ observations & 1058 & 1058 & 1165 & 1165 & 1165 & 1165 \\
\hline$N$ countries & 99 & 99 & 107 & 107 & 107 & 107 \\
\hline
\end{tabular}

Notes: Dependent variable is GrossSR (Gross Savings/GNI). Year-specific time dummies included. Robust standard errors in parentheses (one-step estimation). ${ }^{*}$ Significant at $5 \%,{ }^{* *}$ at $1 \%$. 
Table 4. Static fixed effects estimates (genuine savings rate)

\begin{tabular}{|c|c|c|c|}
\hline & $\begin{array}{l}\text { 'Lack of } \\
\text { corruption' }\end{array}$ & $\begin{array}{c}\text { 'Bureaucratic } \\
\text { quality' }\end{array}$ & $\begin{array}{l}\text { 'Rule of } \\
\text { law' }\end{array}$ \\
\hline & 1 & 2 & 3 \\
\hline \multirow[t]{2}{*}{ GNI per capita $(\ln )$} & $4.096^{* *}$ & $3.453^{* *}$ & $3.500^{* *}$ \\
\hline & (1.059) & (1.105) & $(1.063)$ \\
\hline \multirow[t]{2}{*}{ GDP growth gr-1 $_{t}$} & $0.149^{*}$ & $0.145^{*}$ & $0.148^{* *}$ \\
\hline & (0.059) & (0.057) & (0.057) \\
\hline \multirow[t]{2}{*}{ Age dependency } & -8.695 & -6.083 & -5.844 \\
\hline & $(5.765)$ & $(5.537)$ & $(5.654)$ \\
\hline \multirow[t]{2}{*}{ Urbanisation } & -0.082 & -0.045 & -0.046 \\
\hline & $(0.090)$ & $(0.090)$ & $(0.090)$ \\
\hline \multirow[t]{2}{*}{ Resource exports } & $-0.279^{* *}$ & $-0.137^{* *}$ & $-0.163^{* *}$ \\
\hline & $(0.041)$ & $(0.042)$ & $(0.047)$ \\
\hline \multirow[t]{2}{*}{ Institutional quality } & -0.367 & 0.391 & 0.266 \\
\hline & $(0.287)$ & $(0.351)$ & $(0.270)$ \\
\hline Resource exports* & $0.029^{*}$ & -0.021 & -0.009 \\
\hline Inst. quality & $(0.013)$ & $(0.011)$ & $(0.012)$ \\
\hline $\mathrm{R}^{2}$ within & 0.20 & 0.20 & 0.20 \\
\hline$N$ observations & 1036 & 1158 & 1158 \\
\hline$N$ countries & 99 & 107 & 107 \\
\hline
\end{tabular}

Notes: Dependent variable is GSR (GS/GNI). Year-specific time dummies included. Robust standard errors in parentheses. ${ }^{*}$ Significant at $5 \%$, ${ }^{* *}$ at $1 \%$.

is the interaction effect between the various indicators of institutional quality and resource exports. The interaction between lack of corruption and resource exports (column 1) is positive and significant at the $5 \%$ level. The interactions between bureaucratic quality and resource exports (column 2) and between the rule of law and resource exports (column 3) are not statistically significant, however. There is no evidence here that improvements in these aspects of the political economy will lead to a higher GSR.

The specific interpretation of the statistically significant interaction variable between resource exports and the lack of corruption is that the negative relationship between resource exports and the GSR diminishes i.e. becomes more positive - the less corruption there is. Reducing corruption by one index point increases the slope of resource exports on the GSR by 0.029 units. The coefficient on resource exports shows the slope of resource exports on the GSR at an index score of 0 . Therefore, a one percentage point increase in the resource exports to total exports ratio leads to a decrease in the GSR of 0.28 percentage points in countries with the most corruption. We can make use of the interaction-term coefficient to estimate the slope of resource exports on the GSR at higher scores on the index. At the mean corruption index score of 3.6, a one unit increase in resource exports leads to a decrease in the GSR of only 0.18 percentage points $(0.28-$ $3.6^{*} 0.029$ ), and at the maximum index score of 6 (i.e. at the lowest level of 
corruption), a one unit increase in resource exports leads to a decrease in the GSR of just 0.11 percentage points $\left(0.28-6^{*} 0.029\right)$. Reducing corruption from the maximum to the minimum reduces the negative effect of resource abundance on the GSR by $61 \%$.

Table 5 reports the results of our estimations with the dynamic ArellanoBond model. Of the control variables, GNI per capita and urbanisation are insignificant, GDP growth is significant and positive, while age dependency is sometimes significant and negative. The resources export variable is negative throughout and statistically significant with few exceptions. The interaction effects between our institutional variables and resources exports are not significant in one-step estimation (columns 1a to 3a). However, both the interaction effect between lack of corruption and resource exports (column 1b) and between rule of law and resource exports (column 3b) are positive and significant in two-step estimation. According to these estimations, for a one index point reduction in corruption, the slope of resource exports on the GSR increases by 0.023 units. The respective increase is 0.016 for a one index point improvement in the rule of law. When corruption is at its highest - at an index score of zero - a one percentage point increase in the ratio of resource to total exports leads the GSR to fall by 0.21 percentage points. At the mean corruption index score of 3.6, a one unit increase in resource exports leads to a decrease in the GSR of 0.15 points, and at the maximum index score of 6 (i.e. in the least corrupt state), a one unit increase in resource exports leads to a decrease in the GSR of merely 0.07 points. When the rule of law is at its worst value of zero, a one percentage point increase in the ratio of resource to total exports leads the GSR to fall by 0.19 percentage points. At the mean index score of 4.05 , a one unit increase in resource exports leads to a decrease in the GSR of 0.13 points, and at the maximum index score of 6 (i.e. when there is full rule of law), a one unit increase in resource exports leads to a decrease in the GSR of 0.09 points.

Looking at figure 1 shows that our measure of resource abundance is highly skewed. Most countries have modest ratios of resource to total exports (and mostly positive GS rates), whereas two dozen or so countries have a very high resource exports to total exports ratio (and mostly negative GS rates). One might be concerned that the skewness of this variable influences our results. In sensitivity analysis, we have therefore taken the natural $\log$ of the resource abundance variable and re-estimated all the models. Results were little affected in qualitative terms. Interestingly, the interaction term between lack of corruption and the log of resource exports is now statistically significant even in Arellano and Bond's (1991) one-step estimator. One might be further concerned not only about outliers in terms of resource abundance, but about outliers more generally. If we additionally exclude from the sample observations that have at the same time high residuals and high leverage on the regression results following a criterion described in Belsley et al. (1980), then again our results hardly change. ${ }^{8}$

${ }^{8}$ The leverage of an observation is a multivariate measure of the distance between its $X$ values and the sample means. Observations with a DFITS that is greater 
Table 5. Dynamic Arellano-Bond estimates (genuine savings rate)

\begin{tabular}{|c|c|c|c|c|c|c|}
\hline & \multicolumn{2}{|c|}{ 'Lack of corruption' } & \multicolumn{2}{|c|}{ 'Bureaucratic quality' } & \multicolumn{2}{|c|}{ 'Rule of law' } \\
\hline & $\begin{array}{c}\text { One-step } \\
1 a\end{array}$ & $\begin{array}{c}\text { Two-step } \\
1 b\end{array}$ & $\begin{array}{l}\text { One-step } \\
2 a\end{array}$ & $\begin{array}{c}\text { Two-step } \\
2 b\end{array}$ & $\begin{array}{l}\text { One-step } \\
3 a\end{array}$ & $\begin{array}{c}\text { Two-step } \\
3 b\end{array}$ \\
\hline$(\mathrm{GS} / \mathrm{GNI})_{t-1}$ & $0.356^{* *}$ & $0.367^{* *}$ & $0.359^{* *}$ & $0.386^{* *}$ & $0.353^{* *}$ & $0.357^{* *}$ \\
\hline GNI per capita (ln) & $\begin{array}{c}0.761 \\
(1.912)\end{array}$ & $\begin{array}{c}(0.024) \\
0.980 \\
(1.121)\end{array}$ & $\begin{array}{c}-0.269 \\
(2.195)\end{array}$ & $\begin{array}{c}(0.030) \\
-0.501 \\
(1.200)\end{array}$ & $\begin{array}{c}(0.001) \\
-0.246 \\
(2.002)\end{array}$ & $\begin{array}{c}(0.021) \\
-0.133 \\
(1.106)\end{array}$ \\
\hline GDP growth $_{t-1}$ & $\begin{array}{r}0.189^{*} \\
(0.084)\end{array}$ & $\begin{array}{l}0.165^{* *} \\
(0.021)\end{array}$ & $\begin{array}{r}0.185^{*} \\
(0.076)\end{array}$ & $\begin{array}{l}0.189^{* *} \\
(0.019)\end{array}$ & $\begin{array}{r}0.187^{*} \\
(0.074)\end{array}$ & $\begin{array}{l}0.182^{* *} \\
(0.015)\end{array}$ \\
\hline Age dependency & $\begin{array}{r}-32.655^{*} \\
(15.588)\end{array}$ & $\begin{array}{c}-18.748 \\
(10.351)\end{array}$ & $\begin{array}{r}-28.770^{*} \\
(14.279)\end{array}$ & $\begin{array}{c}-17.747 \\
(14.237)\end{array}$ & $\begin{array}{r}-28.890^{*} \\
(14.017)\end{array}$ & $\begin{array}{r}-21.586^{*} \\
(9.371)\end{array}$ \\
\hline Urbanisation & $\begin{array}{c}-0.088 \\
(0.184)\end{array}$ & $\begin{array}{r}-0.000 \\
(0.126)\end{array}$ & $\begin{array}{c}-0.118 \\
(0.175)\end{array}$ & $\begin{array}{c}-0.095 \\
(0.150)\end{array}$ & $\begin{array}{c}-0.151 \\
(0.163)\end{array}$ & $\begin{array}{r}-0.058 \\
(0.124)\end{array}$ \\
\hline Institutional quality & $\begin{array}{c}0.304 \\
(0.325)\end{array}$ & $\begin{array}{r}-0.057 \\
(0.404)\end{array}$ & $\begin{array}{c}0.037 \\
(0.622)\end{array}$ & $\begin{array}{l}0.108 \\
(0.373)\end{array}$ & $\begin{array}{c}-0.064 \\
(0.471)\end{array}$ & $\begin{array}{r}-0.160 \\
(0.369)\end{array}$ \\
\hline Resource exports & $\begin{array}{r}-0.201^{*} \\
(0.083)\end{array}$ & $\begin{array}{c}-0.211^{* *} \\
(0.033)\end{array}$ & $\begin{array}{r}-0.129 \\
(0.079)\end{array}$ & $\begin{array}{c}-0.137^{* *} \\
(0.037)\end{array}$ & $\begin{array}{r}-0.174 \\
(0.090)\end{array}$ & $\begin{array}{c}-0.192^{* *} \\
(0.026)\end{array}$ \\
\hline $\begin{array}{l}\text { Resource exports * } \\
\text { Inst. quality }\end{array}$ & $\begin{array}{c}0.013 \\
(0.014)\end{array}$ & $\begin{array}{l}0.023^{* *} \\
(0.009)\end{array}$ & $\begin{array}{c}-0.002 \\
(0.017)\end{array}$ & $\begin{array}{c}-0.003 \\
(0.009)\end{array}$ & $\begin{array}{c}0.014 \\
(0.021)\end{array}$ & $\begin{array}{c}0.016^{*} \\
(0.008)\end{array}$ \\
\hline Wald Chi ${ }^{2}$ & 257.2 & 70919.0 & 254.9 & 8201.9 & 261.9 & 3545.4 \\
\hline $\begin{array}{l}\text { 2nd order serial } \\
\text { autocorrelation }\end{array}$ & $\begin{array}{l}-1.63 \\
(0.1033)\end{array}$ & $\begin{array}{l}-1.67 \\
(0.0948)\end{array}$ & $\begin{array}{l}-1.32 \\
(0.1864)\end{array}$ & $\begin{array}{l}-1.32 \\
(0.1863)\end{array}$ & $\begin{array}{l}-1.25 \\
(0.2113)\end{array}$ & $\begin{array}{l}-1.22 \\
(0.2218)\end{array}$ \\
\hline$N$ observations & 844 & 844 & 955 & 955 & 955 & 955 \\
\hline$N$ countries & 90 & 90 & 98 & 98 & 98 & 98 \\
\hline
\end{tabular}

Notes: Dependent variable is GSR (GS/GNI). Year-specific time dummies included. Robust standard errors in parentheses (one-step estimation). ${ }^{*}$ Significant at $5 \%,{ }^{* *}$ at $1 \%$. 


\section{Conclusion}

Resource-rich economies have historically grown more slowly than resource-poor economies, particularly in the last thirty years or so. This is apparently paradoxical, since resource extraction should generate the income to make productive investments in other forms of capital. Resourcerich countries fail to do this. The World Bank's data show that it is the most resource-abundant countries of the world that have also been the poorest genuine savers over the last thirty years, with many of them having persistently negative GS rates. This amounts to an unsustainable consumption of resource rents. More should have been invested in other forms of capital, if these countries were to pursue a more sustainable path. Also, in theory at least, GS performance today will impact future growth performance, so without higher GS, resource-abundant countries are likely to under-perform in terms of future growth relative to resourcepoor countries.

Although some direct economic explanations of the resource curse have been put forward in the past with a modicum of success - most notably 'Dutch disease' effects - it is ultimately policy failure that underpins the curse. This has inspired us to test whether improving institutional quality has a positive effect on the relationship between resource abundance and GS. We have presented evidence on the relationship between institutional quality, resource abundance and GS (as well as gross savings). We asked the question, does improving the quality of a country's political and bureaucratic institutions in various dimensions mitigate the negative effect of resource abundance on the GSR? Atkinson and Hamilton (2003) paved the way for our paper by offering tentative evidence of an interaction between institutional quality in general and resource abundance in determining gross saving/investment: resource-rich countries with good quality institutions have enjoyed higher rates of gross investment and saving. This result was derived in a cross-sectional setting, which might be misleading if the explanatory variables are correlated with country-specific fixed effects. Our panel data design allowed us to control for both countryspecific fixed and dynamic effects. We find some, if limited, evidence that resource abundance in interaction with institutional quality is associated with a higher gross savings rate.

However, it is ultimately genuine savings, not gross savings, that matters for weak sustainable development and we have therefore estimated the impact of the interaction of resource abundance and institutional quality on the GSR. Also, institutional quality is a broad concept and we have attempted to discriminate between different aspects. There are persuasive theoretical and empirical arguments in the literature that suggest corruption may be a major explanatory factor in the resource curse. They often describe a process in which investment is either misdirected or discouraged altogether. A failure to invest resource rents would depress GS, ceteris

in absolute terms than twice the square root of $k / n$ are excluded, where $k$ is the number of independent variables and $n$ the number of observations, and where DFITS is defined as the square root of $\left(h_{i} /\left(1-h_{i}\right)\right)$, where $h_{i}$ is an observation's leverage, multiplied by its studentized residual. 
paribus. In addition, there are arguments for wider political economy effects, summarised in Isham et al. (2003). These explain the resource curse in terms of the control exerted by political elites over resource rents. There is little incentive to develop a competent government bureaucracy and to diversify the national economy into other sectors, a process that the political elites resist through a combination of undemocratic decision-making and repression of more-or-less violent forms.

We have therefore tested three different indicators of institutional quality in the framework of our hypothesis, employing corruption, bureaucratic quality and rule of law indices from ICRG. On the basis of our evidence, we suggest that corruption is a significant cause of a low GSR in resourcerich countries. There is also some limited, but not robust, evidence that improving the rule of law might have a similar effect to reducing corruption.

In a nutshell, the message of our paper is that resource-rich countries can improve their weak sustainability performance by fighting corruption, difficult as this may be. They should ratify and take serious steps to implement the recently negotiated UN Convention against Corruption (www.unodc.org/unodc/en/crime_convention_corruption.html). It is also encouraging to see that the World Bank has promised as part of its Extractive Industries Review to require lending countries to undertake proper and transparent revenue accounting (www.worldbank.org/ogmc/), but one wished it had taken a more outspoken view toward the need to fight corruption in resource-rich countries. This is not to say that countries should only focus on anti-corruption measures: there are many other very persuasive reasons why all aspects of institutional quality should be improved. Indeed, improvements on one dimension are almost certain to lead to improvements in others. Nevertheless, in order to put themselves on a more sustainable investment pathway, we recommend that resourcerich countries as a priority strive to reduce the corrupt practices that stymie investment and make it unproductive.

\section{References}

Acemoglu, D., S. Johnson, and J. Robinson (2001), 'The colonial origins of comparative development: an empirical investigation', American Economic Review 91: $1369-1401$.

Arellano, M. and S. Bond (1991), 'Some tests of specification for panel data: Monte Carlo evidence and an application to employment equations', Review of Economic Studies 58: 277-297.

Atkinson, G. and K. Hamilton (2003), 'Saving, growth and the resource curse hypothesis', World Development 31: 1793-1807.

Auty, R.M. (2001), 'Introduction and overview', in R.M. Auty (ed.), Resource Abundance and Economic Development, Oxford, New York: Oxford University Press, pp. 3-18.

Auty, R.M. and S. Kiiski (2001), 'Natural resources, capital accumulation, structural change and welfare', in R.M. Auty (ed.), Resource Abundance and Economic Eevelopment, Oxford, New York: Oxford University Press, pp. 19-35.

Belsley, D.A., E. Kuh, and R.E. Welsch (1980), Regression Diagnostics: Identifying Influential Data and Sources of Collinearity, New York: Wiley.

Birdsall, N., T. Pinckney, and R. Sabot (2001), 'Natural resources, human capital, and growth', in R.M. Auty (ed.), Resource Abundance and Economic Development', Oxford, New York: Oxford University Press, pp. 57-75. 
Boycko, M., A. Schleifer, and R. Vishny (1995), Privatizing Russia, Cambridge, MA: MIT Press.

Bulte, E.H., R. Damania, and R.T. Deacon (2005), 'Resource intensity, institutions, and development', World Development 33: 1029-1044.

Chaudhry, K.A. (1997), The Price of Wealth: Economies and Institutions in the Middle East, Ithaca and London: Cornell University Press.

Corbo, V. and K. Schmidt-Hebbel (1991), 'Public policies and saving in developing countries', Journal of Development Economics 36: 89-115.

Dayal-Gulati, A. and C. Thimann (1997), 'Saving in Southeast Asia and Latin America compared: searching for policy lessons', IMF working paper, WP/97/110, International Monetary Fund Asia and Pacific Dept, Washington, DC.

Dietz, S. and E. Neumayer (2004), 'Genuine savings: a critical analysis of its policyguiding value', International Journal of Environment and Sustainable Development 3: 276-292.

Edwards, S. (1996), ‘Why are Latin America's saving rates so low? An international comparative analysis', Journal of Development Economics 51: 5-44.

El Serafy, S. (1981), 'Absorptive capacity, the demand for revenue, and the supply of petroleum', Journal of Energy and Development 7: 73-88.

Fankhauser, S. (1995), Valuing Climate Change: the Economics of the Greenhouse, London: Earthscan Publications.

Ferreira, S. and J.R. Vincent (2005), 'Genuine savings: leading indicator of sustainable development?', Economic Development and Cultural Change 53: 737-754.

Glaeser, E.L., R. La Porta, F. Lopez-de-Silane, and A. Shleifer (2004), ‘Do institutions cause growth?', Journal of Economic Growth 9: 271-303.

Gylfason, T. (2001), 'Natural resources, education, and economic development', European Economic Review 45: 847-859.

Hamilton, K. and M. Clemens (1999), 'Genuine saving rates in developing countries', World Bank Economic Review 13 (February), 333-356.

Haque, N.U., M.H. Pesaran, and S. Sharma (1999), 'Neglected heterogeneity and dynamics in cross-country savings regressions', IMF working paper, WP/99/128, International Monetary Fund, Washington, DC.

Hartwick, J.M. (1977), 'Intergenerational equity and the investing of rents of exhaustible resources', American Economic Review 67: 972-974.

Hirschman, A.O. (1958), The Strategy of Economic Development, New Haven: Yale University Press.

Isham, J., M. Woolcock, L. Pritchett, and G. Busby (2003), 'The varieties of natural resource experience: how national resource export structures affect the political economy of economic growth', Middlebury College Economic Discussion Paper, M.C. Department of Economics, Middlebury, Vermont.

Karl, T.L. (1997), The Paradox of Plenty: Oil Booms and Petro-States, Berkeley, CA: University of California Press.

Lane, P.R. and A. Tornell (1996), 'Power, growth and the voracity effect', Journal of Economic Growth 1: 213-241.

Leite, C. and J. Weidmann (1999), 'Does mother nature corrupt?: natural resources, corruption, and economic growth', IMF working paper, WP/99/85, International Monetary Fund African and Research Department, Washington, DC.

Loayza, N., K. Schmidt-Hebbel, and L. Serven (2000), 'What drives private saving across the world', Review of Economics and Statistics 82: 165-181.

Masson, P., T. Bayoumi, and H. Samiei (1995), 'Saving behavior in industrial and developing countries', IMF Manuscript, Washington, DC.

Matsuyama, K. (1992), 'Agricultural productivity, comparative advantage and economic growth', Journal of Economic Theory 58: 317-334.

Mauro, P. (1995), 'Corruption and growth', Quarterly Journal of Economics 90: 681-712.

Moore, B. (1967), Social Origins of Dictatorship and Democracy: Lord and Peasant in the Making of the Modern World, London: Allen Lane Press. 
Murphy, K., A. Schleifer, and R. Vishny (1993), 'Why is rent-seeking so costly to growth', American Economic Review 83: 409-414.

Neumayer, E. (2000), 'Resource accounting in measures of unsustainability: challenging the World Bank's conclusions', Environmental and Resource Economics 15: 257-278.

Neumayer, E. (2003), Weak versus Strong Sustainability: Exploring the Limits of Two Opposing Paradigms, Second Edition, Northampton, MA: Edward Elgar.

Papyrakis, E. and R. Gerlagh (2004a), 'Natural resources: a blessing or curse?', Nota di Lavoro 8, Milan: Fondazione Eni Enrico Mattei.

Papyrakis, E. and R. Gerlagh (2004b), 'The resource curse hypothesis and its transmission channels', Journal of Comparative Economics 32: 181-193.

Prebisch, R. (1962), 'The economic development of Latin America and its principal problems', Economic Bulletin for Latin America 7: 1-22.

Rodrik, D., A. Subramanian, and F. Trebbi (2004), 'Institutions rule: the primacy of institutions over geography and integration in economic development', Journal of Economic Growth 9: 131-165.

Romer, P. (1994), 'New goods, old theory, and the welfare costs of trade restrictions', Journal of Development Economics 43: 5-38.

Ross, M.L. (2001), 'Does oil hinder democracy', World Politics 53: 325-361.

Sachs, J. and A.M. Warner (1995), Natural Resource Abundance and Economic Growth, Cambridge, MA: National Bureau of Economic Research.

Sachs, J. and A.M. Warner (2001), 'The curse of natural resources', European Economic Review 45: 827-838.

Sala-i-Martin, X. and A. Subramanian (2003), 'Addressing the natural resource curse: an illustration from Nigeria', IMF working paper, WP /03/139, International Monetary Fund Research Department, Washington, DC.

Samwick, A. (2000), 'Is pension reform conducive to higher saving', Review of Economics and Statistics 82: 264-272.

Solow, R.M. (1974), 'Intergenerational equity and exhaustible resources', Review of Economic Studies Symposium, 29-46.

Stijns, J. (2002), 'Natural resource abundance and economic growth revisited', Mimeo, University of Berkeley, Department of Economics.

Tol, R.S.J. (2005), 'The marginal damage costs of carbon dioxide emissions: an assessment of the uncertainties', Energy Policy 33: 2064-2074.

Torvik, R. (2002), 'Natural resources, rent seeking and welfare', Journal of Development Economics 67: 455-470.

World Bank (2004), 'World Development Indicators', Washington, DC: World Bank, last viewed at $h t t p: / / w w w . w o r l d b a n k . o r g / d a t a / o n l i n e d a t a b a s e s / o n l i n e d a t a b a s e s . h t m l$ on 16 Feb 2004.

World Bank (2005), 'Where is the Wealth of Nations? Measuring Capital for the XXI Century', Washington, DC: World Bank.

\section{Appendix I. World Bank estimates of GS}

Investment in produced capital, net foreign borrowing and net official transfers are obtained from the national accounts. Although depreciation of produced capital is not, estimates can be derived from data on produced capital formation. The World Bank uses estimates made by the United Nations Statistics Division. Note that net investment in produced capital and foreign assets is aggregated across both the private and public sectors. This means that we are not able to use government consumption or investment to explain GS rates. 
Net depreciation of natural capital can be divided at a basic level into resource extraction on the one hand and environmental pollution on the other. The latter is conceptualised as the use of sink capacity in order for it to be equivalent to capital depreciation. The Bank estimates resource extraction for a range of fossil fuels (oil, natural gas, hard coal and brown coal), minerals (bauxite, copper, iron, lead, nickel, zinc, phosphate, tin, gold and silver), and one renewable resource (forests). Depreciation of natural capital due to resource depletion is computed as the product of price minus average costs of extraction multiplied by the volume of extraction: $(\mathrm{P}-\mathrm{AC}) * \mathrm{R}$, where $\mathrm{P}$ is the resource price, $\mathrm{AC}$ is average cost and $\mathrm{R}$ is the volume of extraction (in the case of a renewable resource $R$ represents harvest beyond natural regeneration). Average costs are used instead of the theoretically correct marginal costs due to a lack of data. Environmental pollution is taken to be the estimated damage cost of carbon dioxide emissions, where each metric tonne of carbon emitted is valued at US\$20. This value is taken from Fankhauser (1995) and is below the median of the more recent meta-analysis of studies estimating the marginal damage of carbon contained in Tol (2005). Note that we omit the damage cost from carbon dioxide emissions from the estimation of GS, following Ferreira and Vincent (2005). This is justified because the damage cost of climate change to the environmental capital stock of a country is not equivalent to the damage of its emissions. Instead, it is the global concentration of carbon dioxide in the atmosphere, a function of global emissions, which matters, in combination with the country-specific vulnerabilities to climate change, which are difficult to model. Empirically, it makes almost no difference to our estimations if the cost of carbon dioxide emissions is included in the GS measure.

Investment in human capital is calculated as net educational expenditures. This includes both capital expenditures as well as current expenditures that are counted as consumption rather than investment in the traditional national accounts. This is regarded as a first approximation to the full value of human capital investment, which is difficult to measure precisely. 